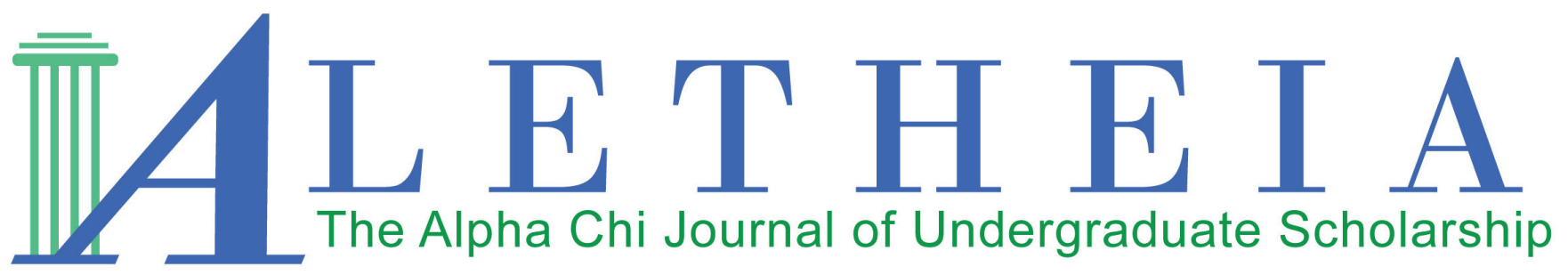

Volume 3 | Issue 1 | 2018

\title{
A Colorful, Classical Correspondence: Greek \& Roman Influences in Thomas Jefferson's Retirement Correspondence with John Adams
}

\author{
Danielle LaRose \\ Cazenovia College \\ New York Tau Chapter
}

Vol. 3(1), 2018

Article Title: A Colorful, Classical Correspondence: Greek \& Roman Influences in Thomas Jefferson's Retirement Correspondence with John Adams

DOI: $10.21081 / \mathrm{AX} 0154$

ISSN: $2381-800 \mathrm{X}$

Key Words: Thomas Jefferson, John Adams, Classics, Classical tradition, Rome, Greece This work is licensed under a Creative Commons Attribution 4.0 International License.

Author contact information is available from the Editor at editor@alphachihonor.org.

\section{Aletheia-The Alpha Chi Journal of Undergraduate Scholarship}

- This publication is an online, peer-reviewed, interdisciplinary undergraduate journal, whose mission is to promote high quality research and scholarship among undergraduates by showcasing exemplary work.

- Submissions can be in any basic or applied field of study, including the physical and life sciences, the social sciences, the humanities, education, engineering, and the arts.

- Publication in Aletheia will recognize students who excel academically and foster mentor/mentee relationships between faculty and students.

- In keeping with the strong tradition of student involvement in all levels of Alpha Chi, the journal will also provide a forum for students to become actively involved in the writing, peer review, and publication process.

- More information and instructions for authors is available under the publications tab at www.AlphaChiHonor.org. Questions to the editor may be directed to editor@alphachihonor.org.

Alpha Chi is a national college honor society that admits students from all academic disciplines, with membership limited to the top 10 percent of an institution's juniors, seniors, and graduate students. Invitation to membership comes only through an institutional chapter. A college seeking a chapter must grant baccalaureate degrees and be regionally accredited. Some 300 chapters, located in almost every state, induct approximately 11,000 members annually. Alpha Chi members have been "making scholarship effective for good" since 1922. 


\title{
A Colorful, Classical Correspondence: Greek \& Roman Influences in Thomas Jefferson's Retirement Correspondence with John Adams
}

\author{
Danielle LaRose \\ Cazenovia College \\ New York Tau Chapter
}

\begin{abstract}
Thomas Jefferson was substantially influenced by Classical Greece and Rome, the lessons from which he shared with John Adams in their retirement correspondence. His friendship with Adams, formed as they worked side-by-side to found a nation, endured the pressures of the party factionalism of the 1790 s only to collapse during the contentious election of 1800 . For over a decade they were not on speaking terms. However, both men corresponded with fellow founder Benjamin Rush who mediated their dispute using the classics as an olive branch. The story of how the classics helped bring them back together is deeply moving, yet it has only been touched upon briefly in the secondary literature. Once resumed, their correspondence was permeated with classical allusions. From then until their deaths on the same day, Jefferson and Adams carried out a colorful, classical correspondence. Jefferson's retirement correspondence with Adams illustrates the profound and far-reaching influence of the classics over him.
\end{abstract}

Key words: Thomas Jefferson, John Adams, Classics, Classical tradition, Rome, Greece

\section{Introduction}

As a young man, Thomas Jefferson was a diligent yet shy student. His father had a limited education, so he ensured his son had the best available which meant a rigorous course-load in the classics. Jefferson was inspired by the great men of antiquity and the classical languages of his studies. After his father's death when Jefferson was fourteen, he turned to the classics as a source of comfort. Like many young men of his day, he kept a commonplace book of quotations from his reading. In the wake of his father's death, he filled its pages with classical passages about grief and living with loss. To fulfill his father's dream for him and pay tribute to his memory, Jefferson delved even deeper into his classical studies. His teacher, Reverend James Maury, an accomplished classical scholar, encouraged him along the way. By the time Jefferson entered the College of William and Mary in 1760, he was a student of the classics par excellence. While there, he studied under Professor George Wythe, who further cultivated his interest in the classics. He apprenticed as a law clerk under Wythe and became a lawyer.

After college, Jefferson's natural charm as well as his classicism endeared him to people and his star rose rapidly. When the stirrings of the Revolution shut down the courts, he was selected to represent Virginia in the Continental Congress. There he joined elite men from the other colonies, many of whom were fellow lovers of the classics. As John Adams recalled in 1822, Jefferson's reputation as a learned man and eloquent writer preceded him at the Congress where his writings were passed around as "remarkable for the[ir] peculiar felicity of expression." While Jefferson was quiet on the 
floor of Congress, he was so "prompt, frank, explicit and decisive upon Committees" that he won the respect and friendship of his fellow founders, particularly John Adams, who considered him his protégé. ${ }^{1}$ The rest-his selection to write the Declaration of Independence, his role in the American Revolution, and his presidency-is history.

Years later, Thomas Jefferson spent his retirement contentedly returning to the classical works he read in youth. The most notable reflection of this was in his classically inspired correspondence with John Adams. The story of how the classics brought them back together after years of animosity is deeply moving. Among the founders, many of whom were educated in the classics, Jefferson and Adams stood out as particularly classically inclined. Friends and fellow patriots for most of their careers, they did not always see eye to eye in their politics, but always held one another in the highest esteem. Even when they fought, their mutual passion for the classics drew them back together again. When the political currents of the early republic made them leaders of the rival Federalist and Democratic-Republican parties, their friendship began to suffer, yet they remained on friendly terms. However, the contentious election of 1800 and the last-minute appointments of Federalist office-holders by Adams, which Jefferson often disregarded, proved to be too much of a strain on the relationship and the two stopped speaking. If Jefferson's account is to be believed, it was Adams who cut him off, but we may never know for sure.

A decade passed in which the two former friends refused to speak to one another, but each continued to correspond with their mutual friend and fellow founder, Benjamin Rush. Rush was thus in the awkward position of corresponding with two former friends who were not speaking. Nevertheless, he knew of their passion for the classics and used it as an incentive to bring them back together. His efforts were a success and in 1812 the two reconciled through Rush (who was actually one of the chief critics of the classics). From then until their deaths (fittingly on the same day), Jefferson and Adams carried out a colorful, classical correspondence.

In their letters, the two old friends discussed many facets of the classical influence and reviewed the important issues and events of the day. They applied classical allusions to topics such as getting older and contemplating their legacies. People tend to discuss the subjects that most strongly influence them with their friends and Jefferson's exchange of letters with Adams encapsulates several key elements of his use of the classics in his correspondence. Thomas Jefferson was substantially influenced by Classical Greece and Rome, the lessons from which he shared with John Adams in their retirement correspondence.

\section{The Classics in Context}

For over two-thousand years, the legacies of Classical Greece and Rome significantly influenced Western history. These civilizations inspired generations of men and women to strive for virtue and excellence; they produced individuals who served as both role models and models of infamy. The republican governments in place during certain portions of their histories continue to shine through as models for government. The history, philosophy, and daily life in these ancient republics were chronicled by wise authors and shrewd politicians whose works are still read widely even today. For centuries, education in the West was synonymous with classical education. First in Europe, then in her American colonies, classical education produced individuals (almost exclusively male) who venerated the classics. This influence was particularly strong in the eighteenthcentury.

At first glance, the largely untamed and provincial nature of Great Britain's North American colonies might seem inhospitable to the establishment and perpetuation of the classics and classical education. However, despite the great distance from the centers of learning in Europe and the lack of tangible Greek and Roman relics to instill pride in cultural heritage, "classical learning was quickly naturalized on American soil." Although the immediate beneficiaries of classical learning in America, as in Europe, were mostly the intellectual elites (such as Jefferson), the "markedly higher level of literacy in America provided a wider audience for the classics." It has even been argued that "never since antiquity were the classics... read by a greater proportion of the population" as they were in eighteenth-century America. ${ }^{2}$

Familiarity with the classics was, therefore, "universal" among educated colonial Americans; among them were the founding fathers, particularly Thomas Jefferson. ${ }^{3}$ By the late eighteenth-century, a young America, like her mother country, reached the zenith of her classical period where learned men, artists, and politicians 
consciously sought to emulate the grand examples of the great figures of antiquity, figures such as Cicero, Aristotle, Tacitus, Livy, and Seneca. ${ }^{4}$ In fact, Jefferson described Cicero's writings as the "most valuable accounts we have of the period" and called Tacitus "the first writer in the world without a single exception." As a result "classical references and allusions run through much of the colonist's writings, both public and private." As Meyer Reinhold notes, this was a unique time in America, a Golden Age when the influence of the classical tradition peaked. ${ }^{6}$ Jefferson was an avid student of this tradition.

Naturally, the classical ideas that were circulating so widely in America were not the same as they were when they were first conceived thousands of years ago. Many classical texts, lost or forgotten during the middle ages, were rediscovered during the Renaissance in monasteries and libraries all over Europe. ${ }^{7}$ Thus, the ideas of the ancients were modified during the Renaissance and by eighteenth-century writers. The Renaissance breathed new life into classical ideas which were then reconstructed and adapted during the American Revolution. Classical ideas were thus influenced by subsequent history.

Therefore, Thomas Jefferson was educated in and contributed to the classics as interpreted through a Renaissance lens. He represents "the culmination of a great tradition of classical culture" transmitted through Renaissance interpretations "to fresh soil" in America. ${ }^{8}$ In turn, each of the three most important sources of inspiration for the founders: ancient history, English history, and America's emerging history (including colonial experiences with self-governance), was interpreted through this lens. As such, Jefferson described Greek and Roman history as "worthy of a good degree of attention" right alongside the histories of England and America. These histories were "inextricably intertwined in the founders' minds." "They did not exist separately as they do in our minds today. This fact muddied the line between ancient ideas and modern ones. Indeed, separating the two may well be an artificial distinction.

Attempts to reconcile the intertwined nature of classical and early modern ideas in the writings of the founders lead to the creation of the historiographical concept of classical republicanism. First outlined by Robert Shalhope in 1972 and elaborated in the works of Bernard Bailyn, Gordon S. Wood, and J.G.A Pocock, classical republicanism is a system of thought concerned with the nature of "citizenship and the polity." ${ }^{10}$ It traces its roots from antiquity, through the Renaissance and the writings of Niccolo Machiavelli, to $18^{\text {th }}$ century Britain and her colonies. Classical republicanism was inspired by the "revival of the ancient theory" that a government based on a mixture of individual and collective power could break the cycle of decay that led to the fall of the great empires of antiquity. ${ }^{11}$ It is a heritage passed through history and used by modern historians to cast light on the founders' relationship with the GrecoRoman writers. The devotion of founders like Jefferson to the classics was part of a long-standing tradition of classical veneration.

The study of ancient history was a "lamp of experience" by which they could search for guidance and parallels in antiquity. This search served two purposes: it increased their sense of legitimacy by rooting their actions, writings, and understanding of their place in the world with "a cultural ancestry reaching back into antiquity" and provided a yardstick against which they could measure their own efforts. For the founders, especially Jefferson, the classics were "the fountains of liberty, of republican forms, and civic virtues, as epitomized by the great classical heroes," and their link to the greatness of the past. ${ }^{12}$ As Jefferson wrote, the ancients left behind "the purest models which exist of fine composition" and "works of reason" which inspired the founders in their endeavors. Accordingly, the classics were used to "look at once backward to the ancient past and forward to a distinctive, modern, American future." 13 This presented a powerful contrast between the past they revered and the future they hoped to forge.

The classics were also a practical tool to apply to contemporary problems. Like many of their pursuits in carving a life for themselves in a new land, the study of the classics by early Americans was eminently practical. Studying Latin and Greek was intended to prepare men for intelligent living and public life. As such, most of the founders were not classical scholars in the traditional sense. They were not professional academics interested in the theoretical applications of the classics. Instead, they were statesmen who used the classics as a functional tool in their quest for political freedom. ${ }^{14}$ The founders turned to the classics as models because they were useful, not because they wanted to study them, at least not in the academic sense. Nevertheless, their immersion in the classics influenced their thought processes. It provided them with time-tested information to help them make sense of the "confusing events of 
their day." The classics informed their perception of the world around them, a world they were hoping to shape for the better. They allowed the founders to clarify their own ideas and helped them construct sound arguments supporting an array of opinions. ${ }^{15}$

These arguments, in turn, created a feeling of precedent that helped the founders persuade themselves and other Americans to rebel against the mother country. They believed that they were continuing the work the classical republicans started "only this time with an unprecedented chance of success." Their republican heroes ultimately lost their battle against tyranny to the likes of Caesar and Augustus, but the founders had a chance to win the war, both literally and figuratively. They saw America as the only place where the classical ideals could be realized. ${ }^{16}$ Jefferson too believed that if any society had a chance to execute the classical ideals and not have them become corrupted, it was American society.

In their pursuit of classical models and allusions, the founders turned to specific periods of Greek and Roman history. As Jefferson remarked, they took great interest in "knowing what passed two or three thousand years ago." Specifically, their Greek allusions and inspiration came from republican Greece through the fourth and fifth centuries B.C. ${ }^{17}$ Their Roman allusions came from the period of the Roman Enlightenment. This era was known as the "Golden Age of Latin literature" and extended "from the breakdown of the Republic around the middle of the first century B.C. to the establishment of the Empire in the middle of the second century A.D.' The authors the founders turned to most were pessimistic Romans such as Cicero, Sallust, Livy, and Tacitus, who wrote during a period when "the greatest days of the Republic were crumbling or already gone." They contrasted the debauchery and vice in their midst with nostalgia for an "earlier republican world" of Roman discipline and virtue, all the while trying to explain the difference. ${ }^{18}$ These Latin writers and their lamentations about an idealized republican past directly informed the concerns of eighteenth-century revolutionaries.

Additionally, the use of classical imagery and culture was a testament to one's class, demonstrating an educated mind and refined taste. Hence, the founders often "enveloped themselves and their causes in classical symbols, much as modern politicians wrap themselves and their policies in the flag." Because the classics were revered in both America and Europe, the founders harnessed them to lend legitimacy to their cause. In this sense, "the classics provided not merely ornaments and delight, but useful guidance in the affairs of daily life" as well as politics. ${ }^{19}$ Like the other founders, Jefferson used the classics as badges of legitimacy, but for him referencing them was about more than that. They were an integral part of his life and he was attached to them emotionally as well as intellectually.

While many of the founders were classically educated and a number of them greatly enjoyed the classics, Jefferson stood out as an "advocate par excellence of the classics" who "bestrode the American scene like a giant." ${ }^{20} \mathrm{He}$ was an "eloquent exponent" of the classical languages and ardently resisted calls for lessening their influence in education. Jefferson "wrote movingly of his love for classical literature" and was thankful that he was able to read it in the original languages. ${ }^{21}$ As he wrote in 1800: "I thank on my knees him who directed my early education" [his primary school teacher James Maury], for the introduction to "this rich source of delight" which he would not "exchange...for any thing [sic]." 22 Additionally, unlike most classically educated men of the time, Jefferson "assiduously" kept up both his Greek and Latin. In contrast with Adams, who struggled with Greek ("if I looked [at] a Word to day [sic], in less than a Week I had to look it [up] again"), Jefferson was a "fluent reader" of both languages. As a result, Jefferson's "lifelong love of the ancient languages was extraordinary even by the standards" of the neoclassical age in which he lived. ${ }^{23}$

There is a large, diverse body of information that testifies to the substantial influence of the classics on Thomas Jefferson. Classical texts comprised the backbone of his libraries and he often encouraged correspondents to root their studies in classical learning. This was especially true in his correspondence with John Adams whom he often lectured about the "fine points of Greek grammar" and the validity of Latin words like 'gloriola.' ${ }^{24}$ In the latter case, Adams asked if "such a Latin word" existed and Jefferson confirmed that the question was "resolved by Cicero," who used it in a letter. ${ }^{25}$ As such, Jefferson's correspondence with John Adams illustrates the profound and far-reaching influence of the classics on him.

\section{A Classical Correspondence}

The friendship between Jefferson and Adams, formed as they worked side-by-side to found a nation, endured the pressures of the party factionalism of the 1790 s only 
to collapse under the pressure of the contentious election of 1800 . For over ten years they were not on speaking terms. However, both men corresponded with fellow founder Benjamin Rush who mediated their dispute using the classics as an olive branch. His efforts were a success and the two men resumed their correspondence.

Beginning in 1812 and encompassing 158 letters over the course of fourteen years, Thomas Jefferson's retirement correspondence with John Adams was full of references to antiquity. These allusions show how deeply both, but especially Jefferson, were influenced by the classics. In the Adams-Jefferson letters, "the most profound student of political science exchanges ideas with the most versatile contributor" to democratic theory and human relations. ${ }^{26}$ Both men read a tremendous amount of ancient history, especially the works of the author Tacitus, who was their "primary favorite." Accordingly, Jefferson once told Adams that the "pithy text of the letter you...sent me....is worthy of the pen of Tacitus," a high compliment. Intellectual but not "pedantic," Jefferson and Adams were "artists in their application of the classical tradition." ${ }^{27}$ These fellow founders spent their golden years re-reading and reflecting upon classical texts and shared the lessons they gleaned from them with one another.

The reconciliation of Thomas Jefferson and John Adams through Benjamin Rush is both heart-warming and demonstrative of the great influence of the classics on their friendship. It is clear that Rush was deeply saddened by the fact that his two friends were not speaking. In 1811, he wrote a thoughtful letter to Jefferson about his "early Attachment to Mr. Adams, and his - to you." Rush reflected on how much the history of the new nation owed to these two goliaths of Americanism working together and lamented the suspension of the friendship that contributed to their ability to work side-by-side to found America. Having corresponded with both men, Rush saw and reflected upon "the sameness of [their] Opinions." It is quite possible that the "sameness" he referred to was their shared passion for the classics. It certainly was not the sameness of their political views which, even years later, were still disparate. Rush stated that his main goal was to see a "friendly... intercourse" revived between Jefferson and Adams. He also had the views of posterity in mind, writing that future generations will "revere the friendship of two Ex-presidents that were once opposed to each Other." He concluded with the suggestion that "an Advance on your Side will be a Cordial to the heart of Mr. Adams." ${ }^{" 28}$ Rush believed that if Jefferson just reached out to Adams, their friendship would reassert itself.

In his reply, Jefferson explained to Rush that politics had divided him from Adams and claimed to hold no illwill toward his old friend. He maintained that Adams was the one who ended the friendship and stated that "I have the same good opinion of Mr. Adams which I ever had. I know him to be an honest man, an able one with his pen." Jefferson believed Adams was alienated from him by "lying suggestions contrived for electioneering purposes" during the election of 1800 . He submitted the facts for Rush to decide whether to mediate. In a subsequent letter, Jefferson related the story of friends who visited Adams and reported him to have exclaimed: "I always loved Jefferson, and still love him[!]" That was all the information Jefferson needed to revive his fondness for Adams. He only wished for a chance to communicate his "unchanged affections" for him. Why, he wrote, "should we be dissocialized by mere differences of opinions in politics [?]" 29 Clearly, Jefferson was ready to resume his relationship with his friend and fellow student of the classics.

Rush responded that he was pleased to hear Jefferson held no ill-will toward Adams and he agreed to act as a mediator. He wrote that he could sense from Adams' letters that he was not doing well and needed a friend. Rush knew that both men loved the classics (even though he himself denounced them) and stressed this point of similarity in his letter. To further incentivize Jefferson to contact his friend, he wrote: "Mr. Adams tells me...that he has lately read several of the ancient Historians \& philosophers, and some of them I beleive [sic] in their original languages for which he is a most strenuous Advocate." ${ }^{30}$ Not only that, but he distinctly refers to Adams as a "strenuous advocate" of reading the ancient authors in their original languages, the very sentiment Jefferson stressed in so many of his letters. Rush understood that Jefferson and Adams agreed upon the importance of the classics. He realized that they could be used as an olive branch to bring the two men back together. Indeed, in December 1811, he encouraged Adam to "receive the olive which has been offered to you by the hand of a man who still loves you." 31

Perhaps Jefferson picked up on Rush's mention of Adams and the classics because he did in fact use them as an olive branch to reconnect with his friend. In his first communication with Adams in over ten years, 
Jefferson wrote that he had "given up newspapers in exchange for Tacitus and Thucydides...and Euclid, and I find myself much happier." 32 He used the classics to reassure his friend that his actions were no longer politically motivated. Instead, his overtures were those of another old patriot whose retirement allowed him to resume his classical reading and who was looking for someone to share it with.

Once Jefferson and Adams resumed their correspondence after years of animosity, Jefferson delicately brought up the subject of politics, the very force that divided them before. He began this conciliatory letter with a passage of Greek from the author Theocritus and assured his friend that he was now "truly Epicurean," and sought "ease of body and tranquility of mind" (friendship is one of the main tenets of Epicureanism). The lines from Theocritus that Jefferson quoted came from a passage where the ancient author described the scene of a woodcutter on Mount Ida who looked at the thousands of trees he had to cut and wondered where to start. Jefferson used the passage to indicate that he, "like the wood-cutter of Ida," knew not how to begin this conciliatory letter to rekindle his friendship with Adams. ${ }^{33}$ It demonstrated his uncertainty and vulnerability in reaching out his friend in a language they both understood. Writing in Greek provided a classical context for his message. After that, "classical motifs remained prominent throughout the letter" which further reinforced Jefferson's pledge of continued friendship. The letter was "as conciliatory as any that Jefferson ever wrote" and he used it to reassure Adams that he had no desire to open old wounds. Thus, he framed their conflict as part of a larger historical process, one that also kept "Greece and Rome in eternal convulsions." 34

Jefferson's "carefully judged classical motif had its desired effect" and Adams responded to his friend's "more universal points" in a letter sent a few weeks later. ${ }^{35}$ In it, he jovially seized upon Jefferson's heavy use of Greek, exclaiming: "Lord! Lord! What can I do with so much Greek?" Several days later, Adams sent yet another letter returning to Jefferson's allusion to the woodcutter on Ida. ${ }^{36}$ He joked that although the woodcutter did not know where to start his labors, he likely knew when to stop unlike Adams who never knew "when to cease" once he got writing to his old friend. ${ }^{37}$ Not only did he acknowledge Jefferson's classical reference, but he cheerfully applied it to their newly-resumed friendship. Their relationship mended, Jefferson and Adams were free to spend their retirement years sharing the influence of the classics with one another.

In the letters that followed, the two fellow founders showcased their mastery of classical concepts. Their correspondence, encompassing 158 letters over fourteen years, "featured exchanges of Greek and Latin quotations, discussion of particular translations...debate about ancient belief" and were peppered with classical references. Both men felt "at home in Latin" and Jefferson actively maintained his command of Greek. ${ }^{38}$ While his Greek was not as strong as Jefferson's and he was sometimes self-conscious about it, Adams was nevertheless able to understand the numerous lines of Greek in his friend's letters. Adams and Jefferson reveled in their classical learning. It was an important part of their late-life friendship, something to bond over. At one point, Adams wrote that the, "Classicks, in Spight [sic] of our Friend Rush [in light of his crusade against classical education] I must think indispensable." 39 Not only did Adams consider the classics to be indispensable to any learned gentleman of his day, but he considered them to be the cornerstone of his friendship with Jefferson.

Within their letters, Adams and Jefferson casually quoted classical phrases from memory (not always accurately) knowing their meaning would be understood. For example, Adams told Jefferson to "Nil Americanum alienum [consider nothing American alien], with the Terentian proverb in mind." ${ }^{40}$ Similarly, Jefferson "bade his friend beware" of "Pickerings... Wolcotts [a reference to dubious officeholders under Adams during his presidency], et id genus omne" [and everyone of that type] (evoking Horace). ${ }^{41}$ Both cited Hesiod's exhortation of man's duty to "honor the immortal gods first, in the order appointed by custom." ${ }^{42}$ Jefferson and Adams also referenced "Sallust and Seneca on civic harmony, the golden rule of Pythagoras, the Elder Pliny on pirates" and related them to the occurrences of their own time. These were not instances of two founders throwing around classical references to save face; both men clearly enjoyed using classical phrases. Each was glad to have someone to share the classics with who would "not recieve [sic] them as if dropped from the moon." Additionally, both mourned the loss of the Sibylline [Prophetic] Books in antiquity and regretted the gaps in the histories written by Livy and Tacitus. ${ }^{43}$ They must have seen the latter as a particularly tragic 
loss considering that he was their favorite ancient author One especially lamentable loss "as much to be regretted as any Production of Antiquity" was that of Cicero's De Republica which only existed in fragments until more was found in $1820 .{ }^{44}$

Another aspect of Jefferson's correspondence with Adams that shows how greatly influenced they were by the classics is a rather lengthy discussion they had about a famous hymn by the Stoic Cleanthes. A great deal of it took place in Greek. Adams viewed it as emblematic of the "divine simplicity which constitutes the charm of Grecian eloquence in prose and verse." ${ }^{45} \mathrm{He}$ even copied and sent pieces of it in Latin, French, and Italian incarnations. Clearly, these men did not use classical quotes simply for effect. They diligently studied the classics and shared their analysis with one another. In their correspondence, they made classical past "their own possession, interpreting it with charm, originality, and relevance." Both men were "at home in all fields of history," especially antiquity. Thus, the correspondence of their retirement years "represents the high-water mark of the classical tradition in colonial writings." Theirs was a truly classical friendship and correspondence.

In the final years of their correspondence, Jefferson and Adams discussed their legacies and mortality. As Richard Gummere wrote, they "philosophically" waited for the end of their lives and commented "peacefully on the history they helped make." ${ }^{46}$ Jefferson confided that he craved a quiet, uneventful retirement. Even in this context, the classics made an appearance when he quoted a line from Horace: "solve senescentum mature sanus equum" (be sensible and turn out the old horse to pasture). He added that "you and I, my dear sir, should not, like Priam of old, gird on the arma desueta trementibus aevo humeris" (arms, long unused on shoulders trembling with age, a paraphrase of Virgil). ${ }^{47}$ Adams and Jefferson agreed that their classicallyinspired lives had been worth living. They did not fear death and each believed in some sort of afterlife. Each defined himself, "as one who summum nec metuit diem nec op tat (neither fears nor craves the close of life)." 48 The classics allowed them to discuss their legacies in a common vernacular. It allowed them to console one another in their old age and make their peace with the inevitability of death. Their classical correspondence helped them forget the aches and pains of old age "in the recollection of antient [sic] times." ${ }^{\prime 8}$

\section{Conclusion}

For Thomas Jefferson and John Adams, the classics were more than just an academic subject; they were the glue that held their friendship together for years and repaired it even after it had been severed. Their passion for the classics was an olive branch when the they needed it most. Once resumed, their correspondence was permeated with classical allusions as well as analysis of classical works and concepts. The classical languages were a common currency between them. They allowed each to write in a form the other would immediately recognize. The relationship between these two great statesmen demonstrates that throughout their lives the classical influence, despite its antiquity, was alive and well in America. Their correspondence highlights the strong influence of the classics on Jefferson.

Although he has had more written about him than any of the other founding fathers, Thomas Jefferson still remains a chimerical figure in American History. His life was so multifaceted and his views so inconsistent that he continues to puzzle researchers to this day. Perhaps this is what keeps drawing us back to studying Jefferson's life and ideas. It is thus ironic that there has never been a book-length study concentrating entirely on the influence of the classics on Jefferson. While a number of authors have touched on elements of Jefferson's classicism, none of them have made it their exclusive focus. Therefore, a comprehensive exploration of this topic would be a fruitful area of study for future researchers.

Determining the extent of the classical influence on Thomas Jefferson has several important implications for modern scholarship. First, knowing the forces that influenced Jefferson's ideas can help us understand why he thought and acted the way he did. Distinctions about the sources of his ideas can help scholars better comprehend Jefferson's notoriously complex thought processes. Every bit of scholarship that contributes to our understanding of what made Thomas Jefferson who he was is therefore beneficial to the scholarly community. Second, applying the classics to the study of Thomas Jefferson shows that the classical influence is still important. The classics have informed Western history for thousands of years and as long as there are scholars interested in studying them they will continue to be relevant. As the Roman historian Livy wrote: "what chiefly makes the study of history wholesome and profitable is...that you behold the reasons for every kind of experience." ${ }^{50}$ In this we are guided by the "lamp of experience" set forth for us by our predecessors. 
Notes

1 "John Adams to Timothy Pickering, 6 August 1822," Founders Online, National Archives, last modified February 1, 2018, <http://founders.archives.gov/ documents/Adams/99-02-02-7674>.

The Classics in Context

2 Meyer Reinhold, Classica Americana: The Greek and Roman Heritage in the United States (Detroit: Wayne State University Press, 1984), 23.

3 Bernard Bailyn, Ideological Origins of the American Revolution (Cambridge: Belknap Press of Harvard University Press, 1992. Originally published 1967), 23-24.

4 Richard M. Gummere, The American Colonial Mind and the Classical Tradition: Essays in Comparative Culture (Cambridge: Harvard University Press, 1963),1-2, quoting S.P. Sherman, The Genius of America, New York, 1923), 200.

5 "Thomas Jefferson to Anne Cary Randolph Bankhead, 8 December 1808," Founders Online, National Archives, last modified February 1, 2018, <http://founders.archives. gov/documents/Jefferson/99-01-02-9252>.

6 Gordon S. Wood, The Creation of the American Republic 1776-1787 (Chapel Hill: The University of North Carolina Press, 1969), 49; Reinhold, Classica Americana, 45.

7 L. D. Reynolds and N. G. Wilson, Scribes and Scholars: A Guide to the Transmission of Greek and Latin Literature (Oxford: Oxford University Press, $3^{\text {rd }}$ edition, 1991), 81-82, 136.

8 Lance Banning, ed by Todd Estes, Founding Visions: The Ideas, Individuals, and Intersections that Created America, (Lexington: University Press of Kentucky, 2014), 111; Louis B. Wright, "Thomas Jefferson and the Classics," Proceedings of the American Philosophical Society 87, no. 3 (1943), 223.

9 "Thomas Jefferson to Thomas Mann Randolph, Jr., 27 August 1786," Founders Online, National Archives, last modified February 1, 2018, <http://founders.archives. gov/documents/Jefferson/01-10-02-0226>; Carl J. Richard, The Founders and the Classics: Greece, Rome, and the American Enlightenment (Cambridge: Harvard University Press, 1994), 82.

10 Robert E. Shalhope, "Toward a Republican Synthesis: The Emergence of an Understanding of Republicanism in American Historiography," The William and Mary Quarterly, Vol. 29, No.1 (Jan, 1972), 49-80; Daniel T. Rodgers, "Republicanism: The Career of a Concept," The Journal of American History, Vol. 79, No. 1 (Jun, 1992), 15-16; Banning, Founding Visions, 44; See also: Bailyn, Ideological Origins of the American Revolution (Cambridge Mass. 1967, 1992); Wood, The Creation of the American Republic 1776-1787 (Chapel Hill, 1969);
J.G.A Pocock, The Machiavellian Moment: Florentine Political Thought and the Atlantic Republican Tradition (Princeton, 1975).

11 Banning, Founding Visions, 64.

12 Reinhold, Classica Americana, 38-39.

13 "Thomas Jefferson to Joseph Priestley, 27 January 1800," Founders Online, National Archives, last modified February 1, 2018, <http://founders.archives.gov/ documents/Jefferson/01-31-02-0289>; S. Onuf and Nicholas P. Cole, eds., Thomas Jefferson, the Classical World, and Early America (Charlottesville: University of Virginia Press, 2011), 18.

14 Reinhold, Classica Americana, 32, 175.

15 Richard, Founders and the Classics, 118; Gummere, The American Colonial Mind, 19; Carl J. Richard, Greeks and Romans Bearing Gifts: How the Ancients Inspired the Founding Fathers, (Lanham, MD.: Rowman and Littlefield, 2008), 180.

16 Richard, Founders and the Classics, 84, 82.

17 "Thomas Jefferson to Nathaniel Macon, 12 January 1819," Founders Online, National Archives, last modified February 1, 2018, < http://founders.archives.gov/documents/Jefferson/98-01-02-0029>; Richard, Founders and the Classics, 74.

18 Wood, Creation of the American Republic, 51.

19 Richard, Founders and the Classics, 39; Wright," Thomas Jefferson and the Classics," 223.

20 Reinhold, Classica Americana, 25.

21 Onuf and Cole eds, introduction to Thomas Jefferson, The Classical World, and Early America, 14.

22 "Thomas Jefferson to Joseph Priestley, 27 January 1800," Founders Online, National Archives, last modified February 1, 2018, <http:/founders.archives.gov/documents/ Jefferson/01-31-02-0289>.

23 "Thomas Jefferson to Francis Eppes, 6 October 1820," Founders Online, National Archives, last modified February 1, 2018, <http://founders.archives. gov/documents/Jefferson/98-01-02-1565>; "John Adams to Thomas Jefferson, 9 July 1813," Founders Online, National Archives, last modified February 1, 2018,<http://founders.archives.gov/documents/ Adams/99-02-02-6098>; Onuf, "Ancients, Moderns, and the Progress of Mankind: Thomas Jefferson's Classical World," in Thomas Jefferson, The Classical World, and Early America, Onuf and Cole eds., 50.

24 Richard, Founders and the Classics, 27-28.

25 "John Adams to Thomas Jefferson, 20 August 1821," Founders Online, National Archives, last modified February 1, 2018, <http://founders.archives.gov/ documents/Adams/ 99-02-02-7534>; "Thomas Jefferson to John Adams, 12 September 1821," Founders Online, National Archives, last modified February 1, 2018, <http://founders.archives.gov/documents/ Jefferson/98-01-02-2309>. 


\section{A Classical Correspondence}

26 Gummere, American Colonial Mind, 192.

27 "Thomas Jefferson to John Adams, 25 November 1816," Founders Online, National Archives, last modified February 1, 2018, <https://founders.archives. gov/documents/Jefferson/03-10-02-0414>; Gummere, American Colonial Mind, 191.

28 "Benjamin Rush to Thomas Jefferson, 2 January 1811," Founders Online, National Archives, last modified February 1, 2018, <https://founders.archives.gov/ documents/Jefferson/03-03-02-0203>.

29 "Thomas Jefferson to Benjamin Rush, 16 January 1811," Manuscript/Mixed Material, Retrieved From the Library of Congress, <https://www.loc.gov/item/mtjbib020491/>.

30 "Benjamin Rush to Thomas Jefferson, 1 February 1811," Founders Online, National Archives, last modified February 1, 2018, <https://founders.archives.gov/ documents/jefferson/03-03-02-0270>.

31 "Benjamin Rush to John Adams, 16 December 1811," Founders Online, National Archives, last modified February 1, 2018, <https://founders.archives.gov/ documents/Adams/99-02-02-5725>.

32 "Thomas Jefferson to John Adams, 21 January 1812," Founders Online, National Archives, last modified February 1, 2018, <://founders.archives.gov/ documents/Jefferson/03-04-02- 0334>.

33 "Thomas Jefferson to John Adams, 27 June 1813," Founders Online, National Archives, last modified February 1, 2018, <http://founders.archives.gov/ documents/Jefferson/03-06-02-0206>.

34 Nicholas Cole, "America and Ancient and Modern Europe," in Thomas Jefferson, The Classical World, and Early America, Onuf and Cole eds., 170; "Thomas Jefferson to John Adams, 27 June 1813," Founders Online, National Archives, last modified February 1, 2018, $<\mathrm{http}$ ://founders.archives.gov/documents Jefferson/ 0306-02-0206>.

35 Cole, "America and Ancient and Modern Europe," Onuf and Cole eds., 170.

36 "John Adams to Thomas Jefferson, 9 July 1813," Founders Online, National Archives, last modified February 1, 2018, <http://founders.archives.gov/ documents/Jefferson/03-06-02-0230>; Over the course of their retirement correspondence Adams wrote roughly three times the letters Jefferson did; See: Gordon S. Wood, Friends Divided: John Adams and Thomas Jefferson (New York: Penguin Press, 2017), 360.

37 "John Adams to Thomas Jefferson, 13 July 1813," Founders Online, National Archives, last modified February 1, 2018, <http://founders.archives.gov/ documents/Adams/99-02-02-6101>.

38 Cole, "America and Ancient and Modern Europe," Onuf and Cole eds., 171; Gummere, American Colonial Mind, 193.
39 "John Adams to Thomas Jefferson, 16 July 1814," Founders Online, National Archives, last modified February 1, 2018, <http://founders.archives.gov/documents/Jefferson/03-07- 02-0357>.

40 Gummere, American Colonial Mind, 193-94, quoting: "John Adams to Thomas Jefferson, 18 December 1787."

41 "Thomas Jefferson to John Adams, 15 June 1813," Founders Online, National Archives, last modified February 1, 2018, <http://founders.archives. gov/documents/Jefferson/03-06-02-0178>. Here Jefferson is referencing controversial figures from Adams' administration: Timothy Pickering, Adams' Secretary of State, whom Adams had to fire due to his opposition to his plans to end the Quasi-war with France (Frederick S. Allis, Jr., and Rob Bartolomei. "Timothy Pickering Papers Biographical Sketch.” Massachusetts Historical Society. September 2006. Accessed April 13, 2018. <http://www.masshist.org/collection-guides/view/ fa0256>), and Oliver Wolcott Jr., one of the "midnight judges" Adams appointed just before Jefferson took office ("Wolcott, Oliver." Federal Judicial Center. Accessed April 15, 2018. <https://www.fjc.gov/history/ judges/wolcott-oliver $>$ ).

42 "John Adams to Thomas Jefferson, 3 December 1813," Founders Online, National Archives, last modified February 1, 2018, <http://founders.archives.gov/documents/ Jefferson/03-07-02-0008>. The original Greek passage from the letter is translated in the accompanying footnotes.

43 "Thomas Jefferson to John Adams, 5 July 1814," Founders Online, National Archives, last modified February 1, 2018, <http://founders.archives.gov/ documents/Jefferson/03-07-02-0341>; Gummere, American Colonial Mind, 193-194.

44 "John Adams to Thomas Jefferson, 16 July 1814," Founders Online, National Archives, last modified February 1, 2018, <http://founders.archives.gov/ documents/Jefferson/03-07-02-0357>; Gummere, American Colonial Mind, 194-195.

45 "John Adams to Thomas Jefferson, [22] September 1813," Founders Online, National Archives, last modified February 1, 2018, <http://founders.archives. gov/documents/jefferson/03-06-02-0409>.

46 Gummere, American Colonial Mind, 195-197.

47 "Thomas Jefferson to John Adams, 27 June 1822," Founders Online, National Archives, last modified February 1, 2018,<http://founders.archives.gov/ documents/Jefferson/98-01-02-2907>; "Thomas Jefferson to John Adams, 27 June 1813," Founders Online, National Archives, last modified February 1, 2018, <http://founders.archives.gov/documents/ jefferson/03-06-02-0206>.

48 "Thomas Jefferson to John Adams, 14 March 1820" Founders Online, National Archives, last modified February $1,2018,<\mathrm{http}$ ://founders.archives.gov/documents/ 
Jefferson/98-01-02-1146:" Translation of line by Martial from: Gummere, American Colonial Mind, 196-197.

49 "From Thomas Jefferson to John Adams, 14 March 1820," Founders Online, National Archives, last modified February 1, 2018, <http://founders.archives.govdocuments/ Jefferson/98-01-02-1146>.

Conclusion

50 Titus Livius (Livy), The History of Rome, Book 1, trans Benjamin Oliver Foster (Cambridge, Mass: Harvard University Press, 1919), Perseus Digital Library.<http:// www.perseus.tufts.edu/hopper/text?doc=Liv.\%201>. 